Relations industrielles

Industrial Relations

\title{
Amendment to our Labour Legislation
}

\section{Jean-Pierre Després}

Volume 1, numéro 8, avril 1946

URI : https://id.erudit.org/iderudit/1023949ar

DOI : https://doi.org/10.7202/1023949ar

Aller au sommaire du numéro

\section{Éditeur(s)}

Département des relations industrielles de l’Université Laval

\section{ISSN}

0034-379X (imprimé)

1703-8138 (numérique)

Découvrir la revue

Citer cet article

Després, J.-P. (1946). Amendment to our Labour Legislation. Relations

industrielles / Industrial Relations, 1(8), 6-8. https://doi.org/10.7202/1023949ar

Tous droits réservés @ Département des relations industrielles de l’Université Laval, 1946
Ce document est protégé par la loi sur le droit d'auteur. L’utilisation des services d'Érudit (y compris la reproduction) est assujettie à sa politique d'utilisation que vous pouvez consulter en ligne.

https://apropos.erudit.org/fr/usagers/politique-dutilisation/ 


\section{AMENDMENTS TO OUR LABOUR LEGISLATION}

On the 28th of March the Lieutenant-Governor sanctioned five labour laws which had been previously passed by the Leglisative Assembly of the Province of Quebec. The bills in question are entitled as follows : $a$ ) An Act to amend the Professional Syndicates' Act (bill No. $22) ; b$ ) An Act to amend the Labour Relations Act (bill No. 25) ; c) An Act to amend the Collective Agreement Act (bill No. 26); d) An Act to amend the Minimum Wage Act (bill No. 27) ; e) An Act to amend the Pipe-Mechanics Act (bill No. 32). The amendments to these labour laws are quite important even though they do not affect the general trend of ourlegislation. Indeed, these amendnents, presented by the Honourable Antonio Barrette, will greatly simplify the carrying out of these Acts and prove highly useful to employees' and employers' associations. A summary of these amendr ents with explanatory notes will be found hereinbelow.

\section{a) Professional Syndicates' Act}

An amendment to section 2 of the Professional Syndicates' Act enacts that the publication, in the Quebec Official Gazette, of the notice authorizing the formation of an association or professional syndicate incorporates the said professional syndicate. Formerly, it was also necessary to deposit this notice in the office of the Superior Court. This simplification of procedure will be appreciated by all the syndicates that have repeatedly requested it.

Section 17 of the Act entitled a syndicate to claim from a member ceasing to adhere thereto an assessment for a maximum period of one year. This section has been amended by reducing this period to three months.

Section 19 of the Professional Syndicates' Act allows municipal corporations to grant an exemption of taxes on immoveables utilized by a syndicate as hall for workmen's meetings. This section has been amended by replacing the word : " workmen's ) by the word : " syndicate $)$.

Finally, bill No. 22 gives a retroactive effect to the provisions of section 1 . In other words, if the syndicates already formed did not deposit the notice of authorization in the office of the Superior Court at the time of their formation, the former procedure no longer binds them to do so.

\section{b) Labour Re!ations Act}

A new paragraph is added to section 7 of the Labour Relations Act. In order to assure itself of the representative character of an association, the Board may, by bylaw subject to the formalities of section 38, determine the conditions on which a person $\mathrm{m}$ ay be recognized as a menber of an association. In the Legislative Assembly, the Honourable Antonio Barrette declared that the enployers' and employees' associations had already been consu'ted about the necessity of drawing up practical by-laws that would ensure a more efficient enforcement of the Act by reducing to the limit the possibilities of jurisdictional disputes between labour associations. The Department of Labour shall in no way whatever interfere in the internal administration of labour unions. On the contrary, the by-laws which will be determined by the Labour Relations Board will make the labour associations' work easier by establishing criterions for the recognition of all professional groups.

Section 19, as newly worded, obliges every association recognized under the Act, and which has entered into a collective agreement, to transmit two certified copies thereof to the Board. Such collective agreement shall not take effect until such deposit is made. Notwithstanding the foregoing provisions, the conditions of work stipulated in the agreement are binding upon the employer and the labour association, but the said association must make the deposit if it intends to protect its rights with regard to any other labour association that would try to obtain certification for the purpose of being recognized in its place. A supplementary paragraph of section 19 makes the provisions of the Labour Relations Act applicable to a collective agreement entered into under the Professional Syndicates' Act as from the date of the deposit of such agreement in the office of the Minister of Labour and provides for the transmission of two copies of such agreement, by the Minister, to the Labour Relations Board.

Other amendments bring up to five (5) the number of members of the Board and deal with the internal administration of that body.

\section{c) Collective Agreement Act}

An amendment to section 10 stipulates that vacations with pay may be rendered obligatory by decree. A second amendment, in conformity with the Apprenticeship Assistance Act, authorizes any parity committee to grant subsidies to apprenticeship commissions.

\section{d) Minimum Wage Act}

Section 2 of the Minimum Wage Act is amended so that it no longer exempts from the application of the ordinances enacted under the said Act the employees subject to a collective labour agreement passed under the Professional Syndicates' Act. The exception is maintained only for employees subject to a decree passed under the Collective Agreement Act.

A new section inserted after section 14 authorizes the Minimum Wage Commission to determine the rate of wages to be paid, for overtime, to an employee engaged and paid by the hour and not subject to a collective labour agreement, and also to determine the vacations with pay to be granted to employees by their employers.

Two paragraphs have been added to section 30 . The first enacts that the prescription of a civil action arising from the Minimum Wage Act or from an ordinance rendered under this Act shall run only as from the first of May following the date of the work done in the case of employees engaged in forest operations. The second paragraph enacts that the mailing of a registered letter from the Minimum Wage Commission to an employer claiming wages for an employment shall suspend the prescription of the action, which prescrip-

(Continued on page 8 ) 


\section{LA SÉCURITÉ INDUSTRIELLE ${ }^{(1)}$}

\section{La VÉRitable PRÉVENTION}

Le premier chapitre de Industrial Safety ${ }^{(2)}$, édité par Roland P. Blake, volume qui est devenu rapidenient et à juste titre le meilleur manuel de sécurité industrielle, nous indique les raisons fondamentales et la synthèse de la technique de prévention des accidents :

$1^{\circ}$ Il y a une cause à chaque accident : celui-ci n'est jamais entièrement l'œuvre du hasard ;

$2^{\circ}$ Il est nécessaire de déceler la cause (ou les causes) d'un accident et de les éliminer, afin de prévenir d'autres accidents de même nature ;

$3^{\circ} \mathrm{Il}$ est enfin plus désriable de découvrir et de faire disparaitre les causes d'accidents avant que ceux.ci ne se produisent.

Ce sont des postulats que nous retrouvons sous diverses formes et à des degrés différents dans les législations de sécurité. Puisque la réglementation du Québec dans ce domaine nous intéresse particulièrement, relisons l'article 4 de la Loi des établissements industriels et commerciaux ${ }^{(3)}$ qui illustre bien l'intention du législateur et son désir de prévenir les accidents et les maladies professionnelles :

"Les établissements industriels et commerciaux " visés par l'article 3 (4) (de la loi) doivent être cons" truits et tenus de manière à assurer la sécurité du " personnel ; et dans ceux qui contiennent des appa" reils mécaniques, les machines, mécanismes, appa" reils de transmission, outils et engins doivent être " installés et entretenus dans les meilleures conditions " possibles pour la sécurité des travailleurs. Ils " doivent encore être tenus dans les meilleures condi" tions possibles de propreté ; offrir un éclairage et " une circulation d'air suffisants pour le nombre des " employés ; présenter des moyens efficaces d'expul" sion des poussières produites au cours du travail " ainsi que des gaz et des vapeurs qui s'y dégagent " et des déchets qui en résultent; offrir, en un mot, " toutes les conditions de salubrité nécessaires à la " santé du personnel, tel que requis par les règle" ments établis en vertu de la Loi de l'hygiène publique " de Québec. "

Notre législation tient donc compte des conditions ci-après qui sont susceptibles de provoquer des accidents, en particulier, des accidents de travail. Voyons toutefois si le texte législatif même complété par la réglementation adoptée en exécution d'icelui, est assez précis pour viser certains risques d'accident et provoquer leur élimination :

(1) Deuxième article d'une série préparée par M. J. O'ConnellMaher ; le premier article a été publié dans le numéro de mars 1946 du Bulletin des relations industrielles;

(2) Prentice-Hall, Inc., New-York, 1943 ;

(3) Statuts refondus de Québec, 1941, chapitre 175 et amendements ;

(4) C'est-à-dire les manufactures, fabriques, usines, chantiers, ateliers de tous genres et leurs dépendances ainsi que les établissements commerciaux, à l'exception : $a$ ) des mines régies par la Loi des mines de Québec ; $b$ ) des ateliers de famille où aucun étranger n'est employé, à moins que ces ateliers soient classés comme dangereux, insalubres ou incommodes ou que le travail s'y fasse à l'aide de chaudières à vapeur ou autres moteurs. $1^{\circ} L^{\prime}$ immeuble: On réalisera immédiatement toute la série d'accidents qui peuvent être causés par un vice ou une faiblesse de construction. Le texte de la loi est assez général, mais il est expliqué à l'article 2 des règlements qui a trait à la construction des immeubles destinés à servir comme établissements industriels :

" La construction des bâtiments de même que les

" changements et modifications qui peuvent y être

" apportés doivent être faits de façon à écarter à

" l'origine les vices d'aménagement, de sécurité ou de

" salubrité auxquels il serait très difficile de remédier

" plus tard. Dans ce but, les plans d'architecte

( doivent préalablement être soumis à l'inspecteur.)

Il y a done contrôle préalable possible de la part du Service d'inspection des établissements industrie's et commerciaux, en ce qui concerne la solidité et l'aménagement de l'immeuble ; cependant, cette vérification est sujette aux standards minima énumérés et analysés ciaprès quant aux points suivants :

Les passages: La réglementation prévoit que les passages principaux doivent avoir au moins 48 pouces de largeur et les passages secondaires, 24 pouces. Est-ce suffisant, même s'il s'agit d'un minimum absolu? Le lecteur tirera ses propres conclusions, surtout s'il sait déjà qu'en exécution de la Loi des édifices publics du Québec, la largeur des allées, des passages et des couloirs, en plus d'être de 30 pouces au minimum, doit être proportionnée au nombre de places destinées aux occupants, soit de 18 pouces par cent occupants.

Conformément aux règlements, les passages doivent être libres. Cette disposition est essentielle et a pour but de prévenir des encombrements et des chutes.

Les issues et les portes: Les portes principales doivent avoir au moins 48 pouces de largeur et 7 pieds de hauteur ; elles doivent toujours s'ouvrir dans le sens de la sortie. Les portes servant d'issue à des corridors ne doivent pas avoir une largeur moindre que celle de ces corridors et si elles doivent servir d'issue en cas de panique, il faut qu'elles s'ouvrent vers l'extérieur.

Notons qu'il n'est pas nécessaire, d'après la loi, que les portes principales soient munies d'une serrure qui s'ouvre automatiquement par pression de l'intérieur, comme c'est le cas pour les édifices publics. Si, dans ce cas, le propriétaire d'un établissement industriel se contente de se conformer aux standards minima, n'y a-t-il pas un danger pour la vie du personnel en cas d'incendie ou de panique?

Les escaliers: Les règlements en exécution de la Loi des établissements industriels et commerciaux décrètent que les escaliers principaux ne doivent pas avoir moins de 4 pieds de largeur et pas plus de 12 pieds entre chaque palier ; qu'il doit y en avoir un nombre suffisant pour permettre l'évacuation immédiate et facile de l'établissement. En vue de prévenir les chutes, la réglementation exige que ces escaliers soient maintenus en bon état et munis de garde.

Cependant, il n'y a aucune prescription relative à la hauteur minimum ou maximum des marches ou à leur profondeur minimum ou maximum. N'y a-t-il pas là une source d'accidents? On retrouve, dans les règle(Suite à la page 2) 


\section{BIBLIOGRAPHIE}

Cette liste, forcément incomplète, indique, sans approuver pour autant leur contenu, certaines publications récentes où le lecteur pourra se renseigner sur l'évolution des idées et des faits dans le domaine des relations industrielles.

\section{VOLUMES ET TRACTS}

Craft Unions of Ancient and Modern Times - John P. Frex American Federation of Labor.

Industrial Relations - Third Conference of American States Members of the International Labour Organization, Mexico City, 1946.

Sécurité syndicale et convention collective - Gérard DION, ptre Cahiers de la Faculté des Sciences sociales de Laval, vol. VI, $\mathrm{n}^{\circ} 2$.

Changements démographiques et professionnels au CanadaMinistère fédéral du Travail.

New Concepts in Collective Bargaining - American Management Association. Personnel Series No. 97.

\section{Périodiques}

CANADA

En relisant les conférences des patrons - Le Travail, avril 1946, p. 8 .

L'assurance-maladie aux Etats-Unis - Le Monde ouvrier, mars 1946, p. 3.

Une charte des relations industrielles pour l'hémisphère occidental Le Monde ouvrier, mars 1946, p. 5.

Conditions Affecting Workers' Family Life - The Canadian Unionist, mars 1946, p. 54 .

Australia's Arbitration System - John Brie Ars.-Trades and Labor Congress Journal, mars 1946, p. 36.

Un programme de travaux de développement recommandé par une commission du B. I. T. - Trades and Labor Congress Journal, mars 1946, p. 45.

National Employment Committee of the Unemployment Insurance Commission - Trades and Labor Congress Journal, mars 1946, p. 7.

Labor, Management Can Work Together - H. Ross Rutherford. - Labour and Learning, Dalhousie University, Halifax, mars 1946.

Veterans are Still Human - Bulletin of the Maritime Bureau of Industrial Relations, Halifax, mars 1946, p. 2.

Medical Services in the Small Industrial Plant - Bulletin of the Maritime Bureau of Industrial Relations, Halifax, mars 1946, p. 6.

\section{ETATS-UNIS}

Negotiating Maintenance-of-Membership Demands - The Management Review, mars 1946, p. 88.

Setting up a Personnel Budget - The Management Review, mars 1946 , p. 85.

Labor Rises Again - American Federationist, mars 1946, p. 15.

Employment Interviewing - The Management News, mars 1946, p. 3.

A Strike Is Right When It Is Moral - The Labor Leader, 16 février 1946.

Today's Encyclicals - Work-by John. Doebele - The Catholic Worker, New York, mars 1946.

\section{FRANCE}

Autour de la Sécuritế sociale-Syndicalisme, Confédération française des travailleurs catholiques, 23 février 1946.

Le travail à la chaine est-il compatible avec la digni té del'homme ?Syndicalisme, C.F.T.C., 9 mars 1946.

\section{AMENDEMENTS A NOTRE LËGISLATION...}

(Suite de la page 4)

Enfin, la Commission pourra, avec l'autorisation du Ministre du Travail et du Lieutenant-Gouverneur en conseil, acquérir, à même ses fonds, des immeubles et des terrains et y ériger des bâtisses pour les fins de son administration et de ses services.

\section{e) Loi des mécaniciens en tuyauterie}

Deux amendements ont été apportés à cette loi. L'un prévoit des pénalités pour les infractions aux règiements et l'autre fixe le pouvoir de réglementer l'exécution de travaux de plomberie dans les municipalités dont la population excède cinq mille âmes.

Enfin, il faut noter que tous ces amendements avaient d'abord été approuvés par le Conseil supérieur du Travail qui groupe des représentants des principales associations patronales et ouvrières ainsi que des économistes et des sociologues.

Jean-Pierre Després.

\section{AMENDMENTS TO OUR LABOUR...}

(From page 6)

tion shall run again for another period of six months as from the mailing of such letter.

Finally, the Minimum Wage Commission may, out of its funds, with the authorization of the Minister of Labour and of the Lieutenant-Governor in Council, acquire immoveables and lands and erect buildings thereon for the jurpose of occupying them for its administration and services.

e) Pipe-Mechanics Act

There are two amendments to this Act. The first provides penalties for contravention to regulations enacted under the Act and the second adds to section 29, as a supplementary provision, the power to regulate the carrying out of plumbing works in municipalities the population of which exceeds five thousand souls.

Finally, it is to be noted that all these amendments had first been approved by the Superior Labour Council, a body which is composed of the representatives of the leading employers' and employees' associations as well as of economists and sociologists.

\section{Jean-Pierre Després.}

\section{INDUSTRIAL SAFETY}

\section{(From page 5)}

angle of staircases or to the nosing of steps and in a specific way. However, we grieve each year about the high number of costly and even fatal accidents in industry, and occurring in staircase traffic. Is there any sound reason for not raising safety standards?

\section{J. O'Connell-Maher.}

(To be continued) 